NBER WORKING PAPER SERIES

\title{
NORWEGIAN AND US POLICIES ALLEVIATE BUSINESS VULNERABILITY DUE TO THE COVID-19 SHOCK EQUALLY WELL
}

\author{
Annette Alstadsæter \\ Julie Brun Bjørkheim \\ Wojciech Kopczuk \\ Andreas Økland \\ Working Paper 27637 \\ http://www.nber.org/papers/w27637
NATIONAL BUREAU OF ECONOMIC RESEARCH
1050 Massachusetts Avenue
Cambridge, MA 02138
August 2020

We thank the editor, Bill Gentry, for extremely helpful comments and suggestions. Financial support from the Research Council of Norway, grants number 283322 and 316475, is gratefully acknowledged. We thank Tiril Eid Barland for research assistance and Statistics Norway for rapid data delivery. Any remaining errors and inconsistencies are our own. The views expressed herein are those of the authors and do not necessarily reflect the views of the National Bureau of Economic Research.

NBER working papers are circulated for discussion and comment purposes. They have not been peer-reviewed or been subject to the review by the NBER Board of Directors that accompanies official NBER publications.

(C) 2020 by Annette Alstadsæter, Julie Brun Bjørkheim, Wojciech Kopczuk, and Andreas Økland. All rights reserved. Short sections of text, not to exceed two paragraphs, may be quoted without explicit permission provided that full credit, including $(\odot)$ notice, is given to the source. 
Norwegian and US Policies Alleviate Business Vulnerability Due to the Covid-19 Shock Equally Well

Annette Alstadsæter, Julie Brun Bjørkheim, Wojciech Kopczuk, and Andreas Økland

NBER Working Paper No. 27637

August 2020

JEL No. H25

\begin{abstract}
We use Norwegian administrative data and applications for emergency government support to simulate magnitude and distribution of business revenue shock due to the Covid-19 pandemic. We rely on it to analyze the impact of business support policies available in Norway and the United States by comparing simulated results from the various policies on a common data set. We find that policies supporting payroll and fixed costs that were available in both countries have a similar impact of reducing firms' economic distress, by cutting the negative effect of the crisis on profitability, liquidity, debt, and solvency by over a half.
\end{abstract}

Annette Alstadsæter

School of Economics and Business

Norwegian University of Life Sciences

P.O. Box 5003, NO-1432 Ås

Norway

annette.alstadsater@nmbu.no

Julie Brun Bjørkheim

Norwegian University of Life Sciences

P.O. Box 5003, NO-1432 Ås

Norway

julie.brun.bjorkheim@nmbu.no
Wojciech Kopczuk

Columbia University

420 West 118th Street, Rm. 1022 IAB

MC 3323

New York, NY 10027

and NBER

wk2110@ columbia.edu

Andreas Økland

Norwegian University of Life Sciences

P.O. Box 5003, NO-1432 Ås

Norway

andreas.okland@nmbu.no 


\section{Introduction}

The Covid-19 pandemic has posed novel challenges to global public health and to the world economy. In most of the Western world, lockdowns closed businesses and services relying on physical proximity overnight. Other businesses saw demand fall sharply due to social distancing measures or experienced supply disruptions. The shock was unprecedented and unexpected, which has made it even harder to assess its magnitude and distribution. This has posed large challenges in shaping and evaluating counteracting policy measures.

To better understand the consequences of economic policy, we examine vulnerability of firms to this kind of revenue loss and ability of policy to weaken the impact. We build on the ideas proposed by Bachas and Brockmeyer (2020) and utilize firm-level administrative records. A lockdown induces a change in revenue and costs. What consequences does that have for profits, liquidity and survival of firms? Financial support to firms can mitigate these effects. To what extent?

We utilize rich Norwegian administrative firm-level data in combination with real time data on the distribution and extent of the economic shock imposed by the Covid-19 crisis to evaluate in a simple simulation framework the effectiveness of various government interventions in mitigating the negative effects of the shock on observable firm-level measures.

The pre-crisis data provide us with information from the firms' balance sheets and profit statements. We also have access to applications of Norwegian firms for emergency support that provide us with information about the distribution of realized revenue losses during the Covid-19 induced crisis. Putting these together, we can study the effect of the crisis taking into account heterogeneity of firms in the economy and consider implications of both actual and counterfactual policy measures. We do so by comparing simulated results for policies from both the US and Norway on a common data set of Norwegian firm, thus enabling us to separate the impact of policies from differences in economic structures. First, we consider an unmitigated shock. Second, we study the impact of policies implemented in Norway. Third, we apply the policy intervention that approximates the Paycheck Protection Program that was implemented in the US.

We find that the shock is large and threatening many businesses, but also that the policy is effective in mitigating it. The impact of the crisis on our measures of profits, liquidity, and solvency falls by over a half both when we model policies available in Norway and those available in the United States. In fact, all fully implemented policy interventions have ultimately fairly similar effects, with the key aspect being support for payroll through the temporary unemployment scheme in Norway or the Paycheck Protection Program in the United States, rather than due to the fixed cost compensation scheme implemented in Norway. 
The Norwegian government imposed the lockdown on March 12, 2020, as a response to the domestic Covid-19 outbreak getting out of control. Economic policy measures to counteract the following drop in output were introduced during the same week. Two main elements of the emergency package were changes in the rules for unemployment insurance and the introduction of a new compensation scheme for businesses. Under the Norwegian system, workers may be laid off temporary or permanently, and both types of layoffs entitle the worker for unemployment benefit payments under the social security system. On March 16, the Norwegian parliament changed the rules for temporary layoffs with immediate effect, drastically reducing the layoff-costs for firms and increasing the compensation amount for the employees. A separate compensation scheme for businesses was first announced on March 27 and passed in the parliament on April 7. The scheme is set to compensate parts of the fixed, unavoidable costs of businesses during the lockdown.

In the US, the massive CARES Act was enacted on March 27. We focus on the small business support scheme part of the CARES Act, that takes the form of loans that are forgivable if firms maintain employment and use the loans primarily for payroll.

We add to the literature on the economic effects of the Covid-19 pandemic and to the understanding of the economic policy response. By relying on micro administrative data and actual measures of revenue loss, we can account for heterogeneity of firms and shocks in the economy in a realistic data-driven way.

Our results are in line with a recent analysis of the Danish crisis measures that allow for both furloughing and fixed costs compensation scheme. In practice, the Danish furloughing scheme is a combination of the Norwegian and US approaches: compensating the employer for wage costs of keeping the employee on the payroll, but disallowing employees from working. Bennedsen et al. (2020) combine a representative survey of more than 10,000 Danish firms during the Covid-19 with 2016 firm-level administrative data, documenting great heterogeneity across sectors in the impact of the crisis. They find that the firms selfreported take-up of the furloughing scheme was the most important correlate of retaining labor.

In this work we don't focus on behavioral or incentive effects and we do not study employment impacts. In a recent analysis, Markussen et al. (2020) utilize the real-time compensation application data, in addition to real-time sector-wise unemployment rates and sector-wise turnover and wage data calculated from 2017 administrative corporate income tax data, to analyze the employment incentives inherent in the current Norwegian cash compensation scheme for businesses. They find that the compensation scheme provides disincentive for maintaining or rehiring the employees and that this can be counteracted by including wage costs in the base for calculating the cash compensation scheme. Employers' incentives under the Norwegian and US policies are not identical — one is an unemployment 
scheme, the other one is wage support. Norwegian employers can choose to lay off workers temporarily and at a fractional scale, but in principle should pay for work that is actually performed. In contrast, in the US, the criterion is employment but not necessarily work, so that the scheme can both substitute for unemployment and for wages for work performed (even if it is not as productive as usual). These differences are undoubtedly important and are worth further studying in future work.

The paper is organized as follows. In Section 2, we discuss the relevant aspect of institutional setting: the lock down and policies implemented in Norway and the Paycheck Protection Act in the U.S. In Section 3 we describe our data sources. Section 4 contains the description of the simulation strategy and Section 5 presents our results, before concluding.

\section{Institutional setting}

\subsection{The Covid-19 lockdown in Norway}

The first case of infection in Norway was recorded on February 26, 2020. By March 12, there were 810 registered cases of infections and one death. As a response to the growing number of domestic cases, the Norwegian government ordered a severe lockdown of the Norwegian society on March 12, 202011 At the same time as the pandemic related uncertainty and the combination of government-imposed and voluntary social distancing were hurting the Norwegian economy, international conditions also worsened rapidly. Norway is an open, oildependent economy. In addition to lower global economic activity hurting the oil price, a price war between OPEC and Russia also contributed negatively. The result was a sharp fall in oil prices, to levels even lower than those seen during the 2014-2016 oil crisis. At the same time, the Norwegian currency depreciated dramatically. Preliminary estimates carried out for the Official Norwegian Expert Group on Covid-19 related economic questions indicate that approximately one-third of the negative economic impact of the pandemic on the Norwegian economy is due to the fall in the oil price and other international conditions (Holden et. al. 2020), while two-thirds is due to domestic government imposed and voluntary social distancing.

\footnotetext{
${ }^{1}$ All childcare and educational institutions were closed. Workers that were able to, were instructed to work from home. Pubs and bars that did not serve food was closed. Restaurants and cafeterias were obliged to ensure more than one meter between each guest, and buffets were banned. In the capital Oslo, serving of alcohol was banned the day after, effectively closing most food serving establishments as well. All entertainment establishments were closed, and all professional and non-professional sport events were canceled. Most of the customer fronting service sector, including hairdressers and physiotherapists, was also closed. However, most shops and malls stayed open, and only individuals in quarantine (due to traveling abroad or having symptoms of or confirmed Covid-19 infection) were explicitly restricted to staying home. Severe travel restrictions were imposed, both domestic and internationally. Public transport was cut back, and all leisure trips and movement were strongly discouraged.
} 
Unemployment increased dramatically during the first weeks of the crisis, when approximately $12 \%$ of the labor force signed up for unemployment benefits. Under the Norwegian system, workers my be furloughed, or laid-off temporarily. $90 \%$ of all the new unemployed were laid off temporarily. As documented by Alstadsæter et al. (2020), there was a clear social gradient in who was laid off during the first weeks of the crisis, with a higher risk of layoff for employees with lower education, lower annual income, and lower hourly wage

\subsection{Norwegian Covid-19 economic measures}

Following the lockdown, the Norwegian government introduced a range of economic measures to support firms and counter the disappearance of activity. This section presents some of the most important measures, focusing on the enhanced temporary layoff scheme and the new compensation scheme for businesses, which are also central to the analysis. These measures are described in more detail in the Appendix.

\section{Enhanced temporary layoff scheme.}

Firms may lay off workers temporarily or permanently. Both options qualify for unemployment insurance benefits for the employee (with potential reductions in the pay level), and induce costs to the employer. Permanent layoffs require severance payments, and in the case of temporary layoffs, the employer must cover wages for the first 15 days of the furlough period $2^{2}$

One of the first responses to the lockdown was to change the rules regarding temporary layoffs. The main purpose was to prevent the breach of the employer-employee link, to enable as many re-hirings as possible after the crisis.

These rules for temporary layoffs were changed as of March 16, reducing the employer's responsibility for compensation from 15 to 2 days. The employee receives full wage payments for the first 20 days of the temporary layoffs up to a cap of NOK 600,000 (measured in annual wage), with reduction in the compensation above the cap. Also, the compensation is reduced from (work) day 21 and onward.

This scheme is in its essence comparable to wage subsidy schemes introduced in other countries. For instance, the Danish and Swedish schemes at first glance appear to be wage subsidies for the firm to maintain employment, in line with the US system described below, as a wage compensation is paid to the employer. But as the employee is not allowed to work for the firm, this is effectively a furloughing/temporary layoff system similar to the Norwegian one 3

\footnotetext{
${ }^{2}$ The maximum duration of temporary layoff of an employee is in total 26 weeks during a period of 18 months. Unemployed persons with prior wage income are entitled to unemployment benefits for a maximum of 104 weeks in general, but for maximum 52 weeks if prior income was low. Unemployed individuals who no longer qualify for unemployment benefits may apply for financial assistance under the social security system.

${ }^{3}$ Many countries introduced varieties of wage compensation/furloughing schemes to prevent permanent
} 


\section{Compensation scheme for businesses.}

On March 27, the government announced a compensation scheme for fixed, unavoidable costs for otherwise sound businesses that experienced a substantial revenue loss as a result of the virus outbreak. Such compensation schemes for fixed costs were also established in several other European countries, where the Swedish, Danish, and British schemes were more similar to the Norwegian, 4

The Norwegian program compensated businesses for their monthly unavoidable fixed costs. The compensation was scaled by the size of the revenue drop they reported for the given month and an adjustment factor. The fixed, unavoidable costs that are eligible for compensation under the Norwegian scheme include rent, utilities, insurance costs, and net interest rate costs 5

The minimum (self-reported) revenue decline to qualify for the scheme was $20 \%$ in March and 30\% in April and May. For businesses that were closed down by the authorities as part of the social distancing measures (such as hairdressers), the compensation constituted $90 \%$ of the revenue loss times the unavoidable fixed costs.For instance, if a firm had unavoidable fixed costs of NOK 1 Million in March and experienced a revenue drop of $70 \%$ due to government closure in March, it would receive NOK 630,000 in compensation for March, as $70 \% \cdot 90 \%=$ $63 \%$.

Businesses that were not closed down by the authorities were compensated at a lower rate, $80 \%$, and the unavoidable fixed costs were also adjusted by a standard deduction. 6

The minimum payable cash support was NOK 5,000, and the maximum payable cash support was NOK 80 Million. For any calculated cash support above NOK 30 million, only $50 \%$ of the amount exceeding this threshold would be paid out.

\subsection{U.S. Paycheck Protection Program}

The business support package for small businesses implemented in the US was structured quite differently than the one in Norway. Naturally, US firms also can reduce their labor costs by laying off workers. But in the absence of easily accessible temporary layoff scheme, this is likely to have more adverse consequences for retaining firm-employee linkages. One of

layoffs, including Denmark, Sweden, the Netherlands, France, Germany, Italy, UK, US. See Bennedsen et al. (2020) for a more thorough description of the various schemes.

${ }^{4}$ Under the British, Swedish, and Danish schemes, a given percentage of fixed costs, up to a cap, is paid to firms experiencing severe revenue decline and/or who were shut down by the government as part of social distancing measures. Germany, The Netherlands, and France instead offered lump-sum payments to firms. See Bennedsen et al. (2020) for a more thorough description of the various schemes.

${ }^{5}$ The specific rules were announced on April 2, and the legislation was passed by the parliament on April 7 and revised on May 15: https://www.regjeringen.no/id2702881/

${ }^{6}$ The deduction was NOK 10,000 for March and NOK 5,000 for April. 
the objectives of the US CARES Act, enacted on March 27 and subsequently extended, was to help firms in preserving employment.

We will focus here on one component of the CARES Act: The Paycheck Protection Program which provides support to small (generally under 500 employees, with some exceptions) businesses 7 The program provides an alternative to layoffs. Firms that are affected by the crisis can apply for a loan to be used over a 24-week period that can be up to 2.5 times average monthly payroll cost (or USD 10 Million, whichever is lower). If the firm maintains employment and salaries above $75 \%$ of those in the baseline period and uses at least $60 \%$ of the loan for payroll (the rest can be used for mortgage interest, rent or utilities), the loan turns into a grant and is forgiven. There are other limitations and rules, for example relating to limitations on the employee compensation that can be covered (up to USD 100,000). Most importantly, this is an option of a substantial support that presents an alternative to reducing labor costs via laying off workers.

We will investigate a stylized version of this policy adopted to the Norwegian environment and availability of the data.

\section{Data}

\subsection{Administrative data}

We utilize very detailed, de-identified administrative firm-level data from Statistics Norway covering the universe of Norwegian corporations.

Corporations submit income tax forms with detailed profit and balance sheet information. The data source provides us with the main variables used in this analysis: firms' operating profits and its underlying components.

We utilize the most recent data set available, from the end of 2018. The corporate income tax statement for 2019 was not supposed to be due until May 2020 and, subsequently, the deadline has been extended until August 2020 as part of the Covid-19 measures 8 The key assumption is thus that the firm-level tax statement data from end 2018 give a reasonable representation of the structure of the Norwegian economy going into 2020.

We exclude from our sample corporations in sectors that do not qualify for the cash compensation scheme (described in more detail in the Appendix), including the oil sector, which then removes some of the more structural differences between Norwegian and US firms. We also require that firms have real economic activity in order to be included in the sample,

\footnotetext{
${ }^{7}$ For more info on the program, see https://home.treasury.gov/policy-issues/cares/assistance-for-smallbusinesses

${ }^{8}$ For more information about corporate tax data and variables in the data delivered by Statistics Norway, see https://www.ssb.no/data-til-forskning/utlan-av-data-til-forskere/variabellister/regnskap
} 
by including only firms that have positive turnover and non-negative wage costs, fixed costs, and material input costs. This leaves us with a total of 158,380 firms that serve as the base for our simulations.

\subsection{Real-time data}

We supplement our (historical) administrative data with real time data in Firms' revenue losses and layoffs in order to use have realistic description of the crisis in our simulations. Unfortunately, these real time data cannot be merged with our administrative micro data. Instead, we use these data to measure revenue loss and layoff-rates by sector and incorporate it into the simulations based on the administrative data from the end of 2018 .

\section{Cash compensation for businesses.}

The Covid-19 compensation scheme for businesses is administered by the tax administration. Since the firms' 2019 income tax statements are yet to be submitted, there are no official records for 2019 to compare the firms' self-reported revenue loss to. As a measure to prevent fraud, the full name of the firm being granted cash support is published, along with its organization number, location, sector code, and self-reported turnover for the corresponding support month (March, April, or May) for 2020 and 2019, as well as received cash compensation. This information is updated daily in an easily downloaded format and has been widely utilized also by journalists $\bigsqcup^{9}$ There is a lag in the registration of compensation applications and cases, so for the current paper, we will base the analysis on the compensations for March - the only month, for which complete data are available at the time of this work.

\section{Unemployment data.}

The generous rules for temporary layoffs, effectively reducing the costs to the businesses of laying off employees, as well as providing full wage compensation to the temporarily laid-off employees lead to a sharp increase in unemployment. We use sector-wide unemployment rates from Markussen et al. (2020).

\subsection{Variable definitions}

Based on the corporate income tax statements, we have detailed information on the various components of the operating costs. Material input costs are costs of goods bought including fees, and we use this variable in the simulation of the firms' short-term cost reduction responses, assuming that they can cut these costs in line with turnover in the short term.

\footnotetext{
${ }^{9}$ Updated data are available at https://www.skatteetaten.no/presse/innsyn-kompensasjonsordning.
} 
Labor costs include wages, payroll taxes and fees. Remaining costs is a residual that picks up other types of fixed costs and variable costs. We use these detailed accounts to construct standard ratio indicators of profitability, liquidity, and solvency: namely the profit margin, the quick ratio, and the debt ratio.

The profit margin is constructed as operating profits divided by revenue. From the data, we construct operating profits as turnover net of material costs, labor costs, and other nonfinancial costs.

We construct a short-term liquidity measure to indicate the firm's short-term ability to pay its bills. To do so, we focus on current assets and current liabilities. Because inventories are the least liquid asset, especially in the context of this crisis, our short-term liquidity measure excludes inventories 10 We thus construct the quick ratio as current assets net of inventories, over current liabilities.

The most commonly used solvency measure, the debt ratio, indicates the firm's long term ability to meet its obligations. We define the debt ratio as total debt over total assets.

In order to simulate the effects of the compensation scheme for businesses, we construct a separate variable for unavoidable fixed costs based on the regulations for this scheme described in more detail in the Appendix.

\subsection{Descriptive statistics}

Table 1 shows basic summary statistics for over 158,000 active corporations in our data at the end of 2018. The average revenue is approximately NOK 27 Million (USD 2.7 Million ) with an average profit rate of about $11 \%$. Material/variable costs are the biggest component, followed by labor costs. As usual with level firm data, there is tremendous variation in all of these variables.

Figure 1 shows self-reported revenue loss for all firms for March. The bulk of the decline in activity took place only after March 12. At the time of writing this article, we did not yet have complete coverage of April filings (that would cover the whole month), so instead we rely on the scaled version of March figures. The distribution of losses is widespread, with firms with 100\% revenue loss even though the data covers a month that was not fully affected by the lockdown.

In order to simulate the distribution of losses for the full month we proceed by scaling up the March figures by $133 \%$. This naturally results in a much larger mass at $100 \%$ revenue loss than that visible in Figure 1 but is selected to be broadly consistent with the incomplete April numbers.11

\footnotetext{
${ }^{10}$ Also, some types of inventories might also perish or depreciate in value if a firm has to close down unexpectedly.

${ }^{11}$ At the time of writing this paper, the number of firms with an approved applications for assistance in April was 20,515 compared to 23,992 in March, 15\% smaller, despite the expectation that the ultimate
} 
Table 1: Summary statistics

\begin{tabular}{lrr} 
& Mean & Standard deviation \\
\hline Revenue & 27,740 & 313,630 \\
Total costs & 26,106 & 295,979 \\
$\quad$ Labor inputs & 5,340 & 48,032 \\
$\quad$ Material costs & 13,448 & 213,233 \\
$\quad$ Fixed operating costs and other costs & 4,432 & 104,772 \\
$\quad$ Fixed unavoidable costs* & 2,886 & 35,921 \\
Profits before taxes & 1,633 & 35,561 \\
$\quad$ & & \\
Profit margin & 0.11 & 0.31 \\
Quick ratio & 1.793 & 1.836 \\
Debt ratio & 0.691 & 0.3162 \\
Number of firms & 158,380 & \\
\hline
\end{tabular}

Based on 175,281 Norwegian firms as of December 2018. All amounts are in thousands of Norwegian Krone $(1 \mathrm{NOK} \approx 0.1 \mathrm{USD}$ as of June 2020$)$. The profit margin, quick ratio, and debt ratio are fractions. The definition of fixed unavoidable costs follows from the Norwegian support scheme, and thus *includes net financial costs.

The effects of the lockdown shock were heterogeneous in nature. Some sectors were forced to close down by the government, while others kept regular activity levels (Alstadsæter et al. 2020). Figure 2 illustrates variation across industries in the effect of the crisis, as revealed by the application data. Industries vary widely in terms of the effect of the crisis. There are industries where few eligible firms applied and some industries where the majority of firms applied. This is correlated with revenue loss conditional on applying - industries with more firms applying, have on average higher revenue loss than those with few firms that apply. However, even within the industries with few applicants, those that do apply exhibit large losses, in almost all cases exceeding $50 \%$ of revenue on average.

The two dimensions in Figure 2 are the inputs into our simulation. An industry is characterized by the share of firms applying and the (average) revenue loss conditional on application. These two dimensions combined generate wide heterogeneity in the effect of the crisis across industries. Figure 3 combines them to obtain an estimate of the revenue loss for firms in the industry as a whole, including firms that did not apply. We assign a $10 \%$ loss (half of the level for eligibility) for non-applicants and use the actual percentage loss for applicants, and combine the two. The figure succinctly illustrates the wide heterogeneity in

number will be larger and explainable but not yet complete processing. We selected $133 \%$ adjustments to March revenue loss to approximate the number of firms with full reported loss of revenue in April. 19.8\% of April applicants reported $100 \%$ loss of revenue and inflating March figures by $133 \%$ yields almost precisely the same share of $19.8 \%$. The adjustment by $150 \%$ would result in $35.5 \%$ of firms with full revenue loss, while a smaller factor of 1.2 would give just $10.12 \%$ 
Figure 1: Self-reported revenue decline in March

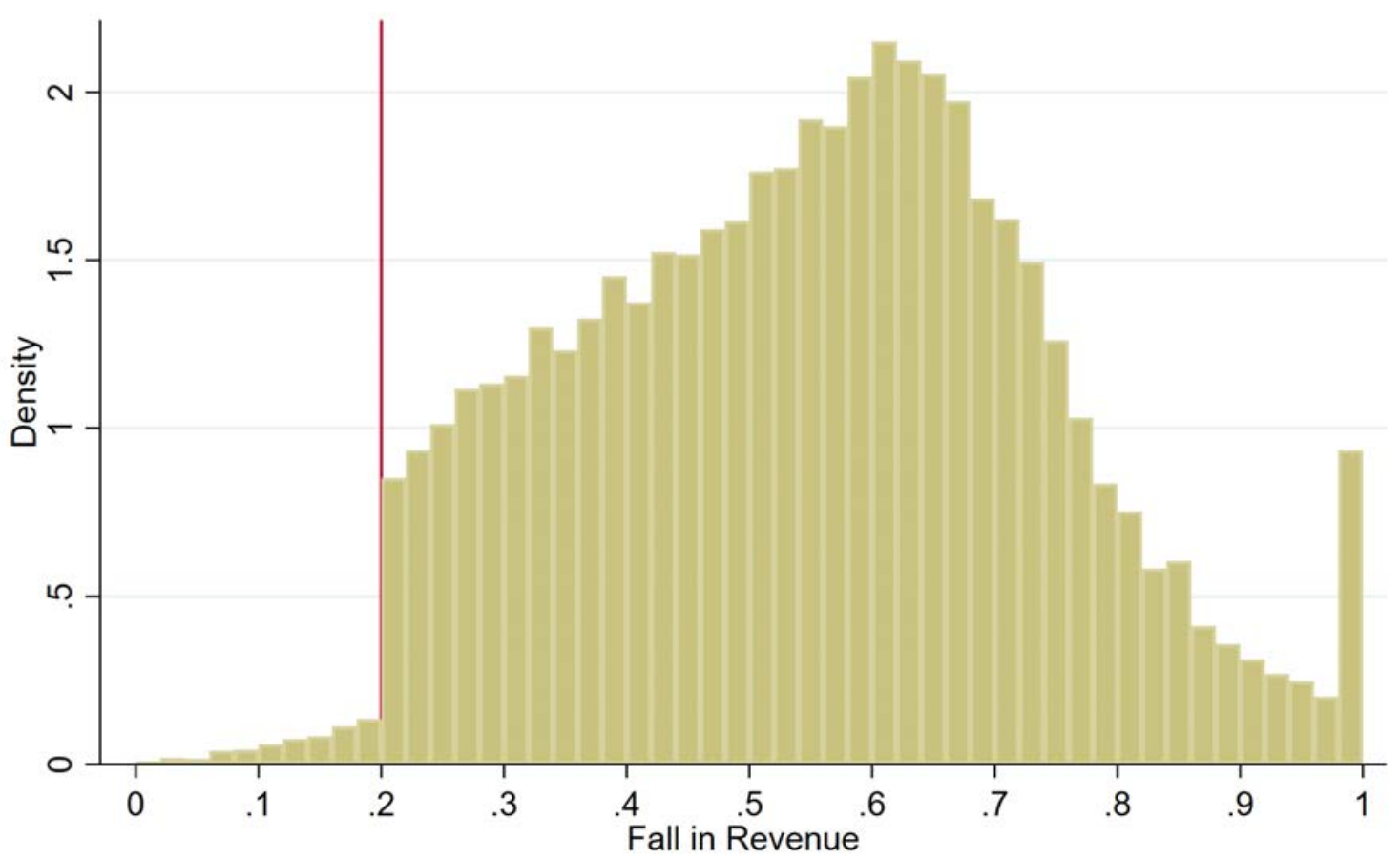

Notes: Density of self-reported revenue drop as reported in the application for the compensation scheme for businesses. The vertical line is the cutoff for compensation.

the economy.

\section{Simulation strategy}

Our simulation strategy builds on the micro data to model heterogeneity of firms and the impact of the crisis and incorporates the most important policy measures for Norway and the US: the compensation scheme for businesses and the enhanced temporary layoff scheme for Norway, and the PPP scheme for the US.

While our real-time cash support and unemployment data allows for observing the magnitude of the shock and the administrative data allows for observing detailed pre-crisis financial information about firms, we cannot link the real-time data to the administrative register data on firm level. Instead, we account for heterogeneity in the effect of the crisis by drawing from a simplified distribution of the shock conditional on industry. These industry-specific distributions are characterized by two parameters: the likelihood of applying and the average revenue loss conditional on applications, as illustrated in Figure 2 .

Each firm in the administrative data is included, with weights, in each of the two regimes; the application regime and the non-application regime. Firms in the application regime are 
Figure 2: Turnover drop for reporting firms

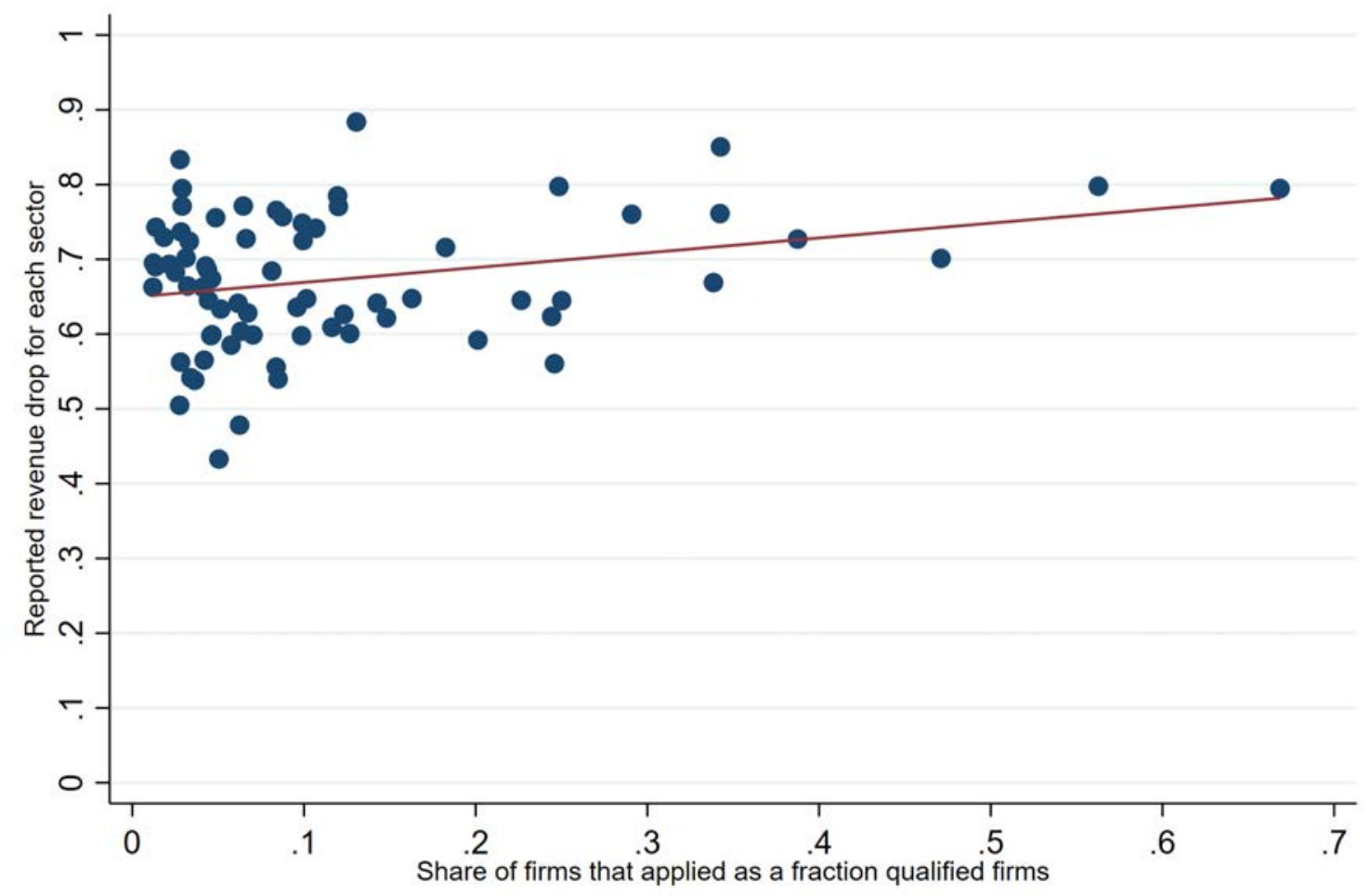

assigned an industry-specific revenue loss based on actual applications and weighted by the applications share in their sector from the application data. Firms in the non-application regime are assigned a 10\% turnover drop (half of what is required for eligibility for the Norwegian cash support) and weighted by the non-application share in their sector. The distribution reflects the mix of the two regimes consistently with the application shares and the average revenue loss in each regime is consistent with the data.

This approach does not attempt to match the correlation of revenue loss with firm characteristics beyond the industry level — we do not have sufficient information to do so. In particular, we will proceed by reporting averages across firms without weighting by revenue or other characteristics to avoid the impression that this procedure mimics the precise distribution within industries. Despite this limitation, the approach allows for a lot of heterogeneity for the economy as the whole due to first-order heterogeneity in the impact of the crisis across industries and non-trivial heterogeneity within industries due to the interior and heterogeneous application rate. 
Figure 3: Simulated revenue loss and applications, all firms, by industry

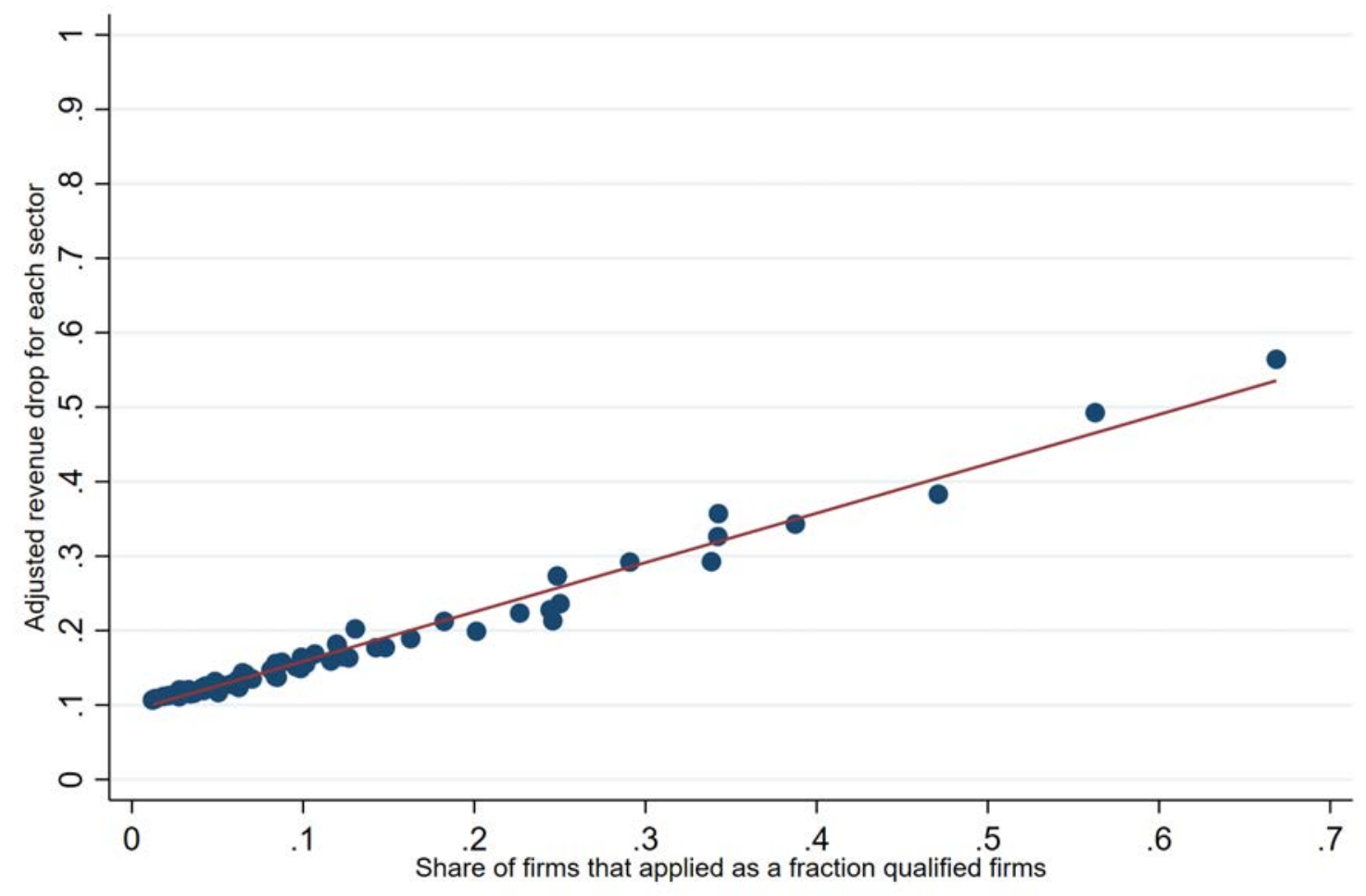

\section{Introducing Norwegian policies.}

When the government introduced the enhanced temporary layoff scheme, it enabled firms to layoff employees almost immediately with full compensation for the employees. We use the first month of real time data on layoffs, on a sector level, to assign firms a fall in monthly labor costs during the lockdown. This has been facilitated by the changes in policy that reduced costs of laying off workers temporarily.

When estimating the potential compensation for unavoidable fixed costs that each firm is eligible for, we consider the rules and restrictions described in Section 2.2 above. In particular, we take into account that a firm cannot receive more than NOK 80 Million in compensation for one month and that every NOK in compensation exceeding 30 Million is cut in half.

\section{Introducing the US policy.}

Modeling the PPP requires adapting it to the Norwegian situation and our data. First, while the US scheme does not have an explicit revenue reduction eligibility criterion, we assume 
that firms that meet the revenue loss criteria in Norway are eligible for the stylized PPP scheme. This approximates the PPP requirement of eligibility that extends to firms that were financially affected by the crisis. Second, the scheme covers up to 2.5 times monthly payroll to be used over 24 weeks. We interpret it as the monthly amount equal to $2.5 / 6 \approx 0.4166$ of monthly payroll. Third, we assume that a firm that chooses to apply for PPP does indeed maintain employment and qualifies for forgiveness so that this becomes a grant rather than a loan. Fourth, we convert the maximum amount of USD 10 Million over 24 weeks to NOK16 million per month. Our data do not account for individual employee salary limitations and other criteria.

We consider two variants of the response to PPP. In the first one, firms maintain full payroll. In the second one, firms reduce payroll to $75 \%$, which is the minimum that allows for full forgiveness of the loan. While PPP payments can be used for payroll or fixed costs, our assumption of maintaining employment and payroll of at least $75 \%$ implies that the split of funds between those two categories is not relevant.

When considering PPP, a firm considers its costs net of the PPP payment and compares it to the cost if it laid off employees, choosing the lower of two. The potential layoffs if the firm were to forego PPP are assumed the same as in the simulation using the Norwegian policy (the layoff rate set at industry level).

This assumption ignores any non-immediate financial motivations that firms might have in deciding whether to take up PPP, such as preserving employment links, that might lead to take up even if the financial consequences of layoffs are more appealing. Unfortunately, we do not have empirical evidence on this question.

\section{Scenarios for the simulations.}

In each of the simulations below, we consider six different scenarios. The baseline scenario is just the situation as of December 2018. The Revenue shock scenario shows the impact of the industry-specific revenue decline in the absence of any government interventions or layoffs, where the only response margin for the firm is a reduction in material costs in proportion to revenue loss. The next two scenarios include the Norwegian government interventions. Fixed cost policy scenario includes the cash compensation for unavoidable fixed costs in addition to the reduction in material costs, and the Fixed cost and layoffs scenario additionally allows firms to reduce costs by laying off workers (implicitly, that corresponds to the unemployment insurance system bearing the cost). The last two scenarios introduce the impact of the stylized US PPP compensation scheme. The scheme gives firms the right to a given compensation, conditional on retaining workers. The PPP scenario shows the effect of the firms keeping employment fixed and receiving the compensation. The PPP, 75\% Payroll scenario shows the

impact when the firm utilizes the opportunity to receive compensation and retains workers 
Figure 4: A change in annual profits in response to a 1-month shock in revenue and policy

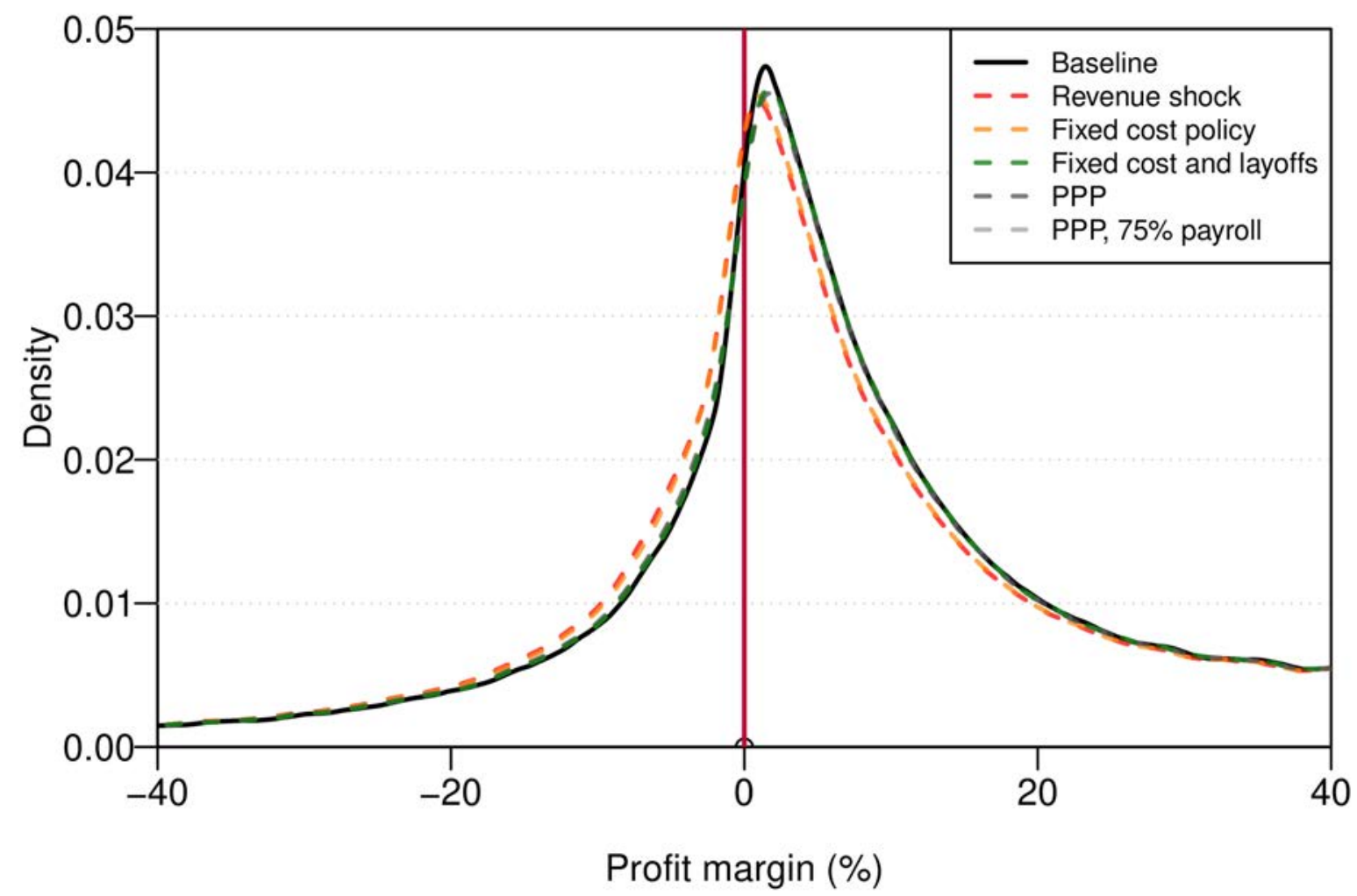

but reduces payroll costs to $75 \%$ of the prior level that still makes it eligible for receiving the full compensation.

\section{$5 \quad$ Results}

We begin by considering the effect of the crisis on annual profits. Figure 4 illustrates the impact under several scenarios, assuming that the shock lasts just one month. Norwegian firms are on average profitable, although with a substantial distribution of the profit margin. In the most extreme scenario, we assume that the firms experience a revenue shock and only material costs adjust in proportion to the revenue decline. All other scenarios correspond to mitigation through policy.

The shock unambiguously shifts the distribution to the left, but most firms remain profitable. The Norwegian fixed cost scheme is almost indistinguishable from experiencing the full shock - the implications of this transfer for the annual profit rate are trivial. On the other hand, labor cost adjustments via (temporarily) laying off workers or taking advantage of the PPP program do make a real difference, bringing the distribution much closer to the 
Figure 5: A change in annual profits in response to a 3-month shock in revenue and policy

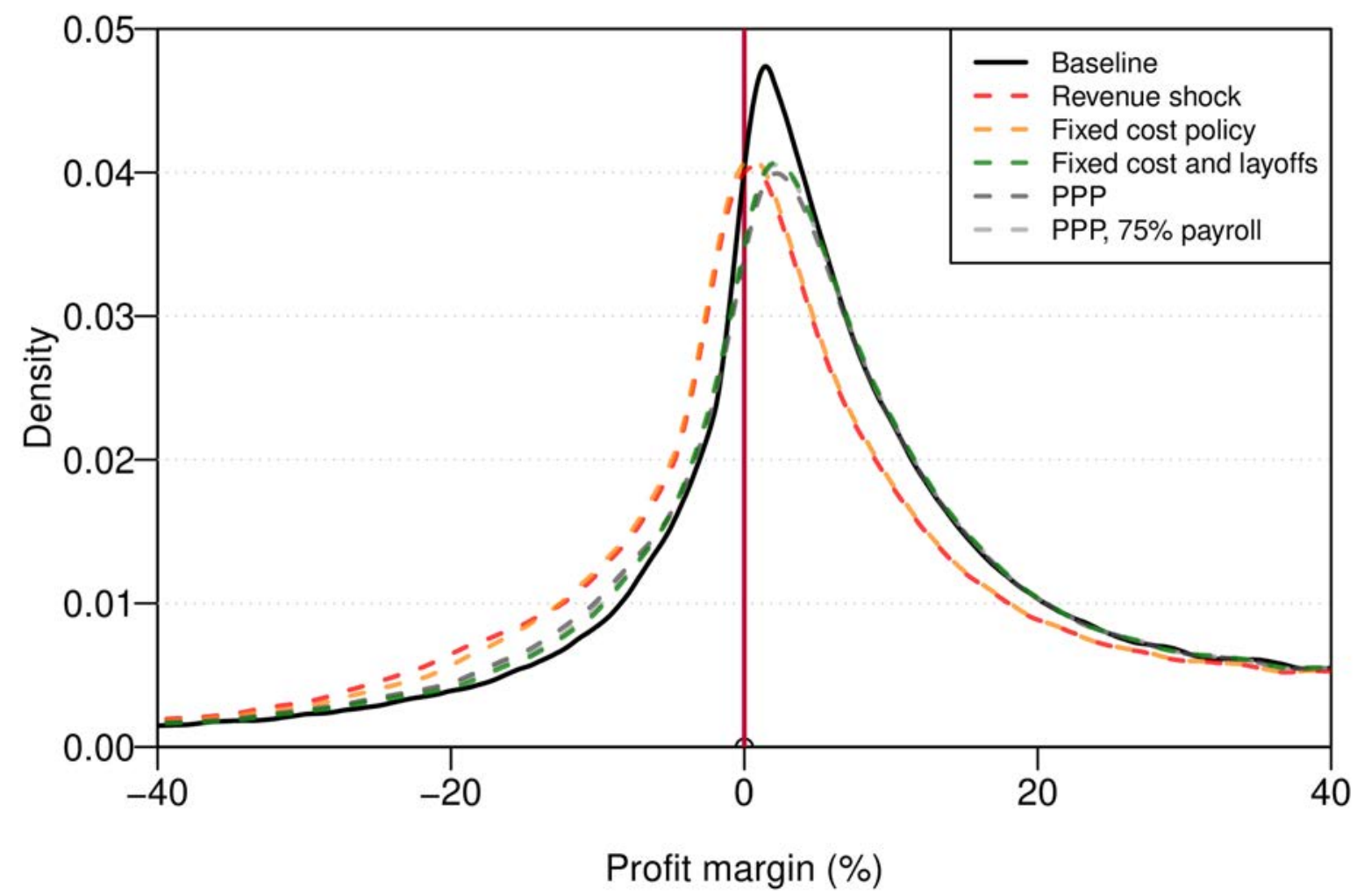

original one.

Figures 5 and 6 show the impact of the same revenue shock lasting for three and six months. The consequences are much graver and progressing over time. The left tail of the distribution of firms under the unmitigated shock is now thicker and the mode is now close to zero. The fixed cost scheme makes again little difference. However, the adjustment of labor costs significantly reduces the number of firms with negative annual profits.

The first two rows of each panel of Table 2 show the impact on the annual profit rate of a shock lasting 1, 3 and 6 months, respectively, under different scenarios. On average, the unmitigated profits rate falls from $9.9 \%$ to $9.0 \%$ after 1 month, to $6.9 \%$ after 3 months and to just $3.1 \%$ after 6 months (all numbers on the annual basis). The Norwegian fixed cost scheme alone does little to help if workers are not laid off, but any of the labor-related actions have similar impact in terms of the profit rate, cutting the magnitude of the effect by between a half and two-thirds.

Even more dramatically, as many as $9.7 \%$ of additional firms would have a negative profit rate if the shock persisted for 3 months, but the layoffs or PPP reduce the magnitude of that increase dramatically, to 2.1 or $2.8 \%$. The impact is even larger after 6 months - instead 
Figure 6: A change in annual profits in response to a 6-month shock in revenue and policy

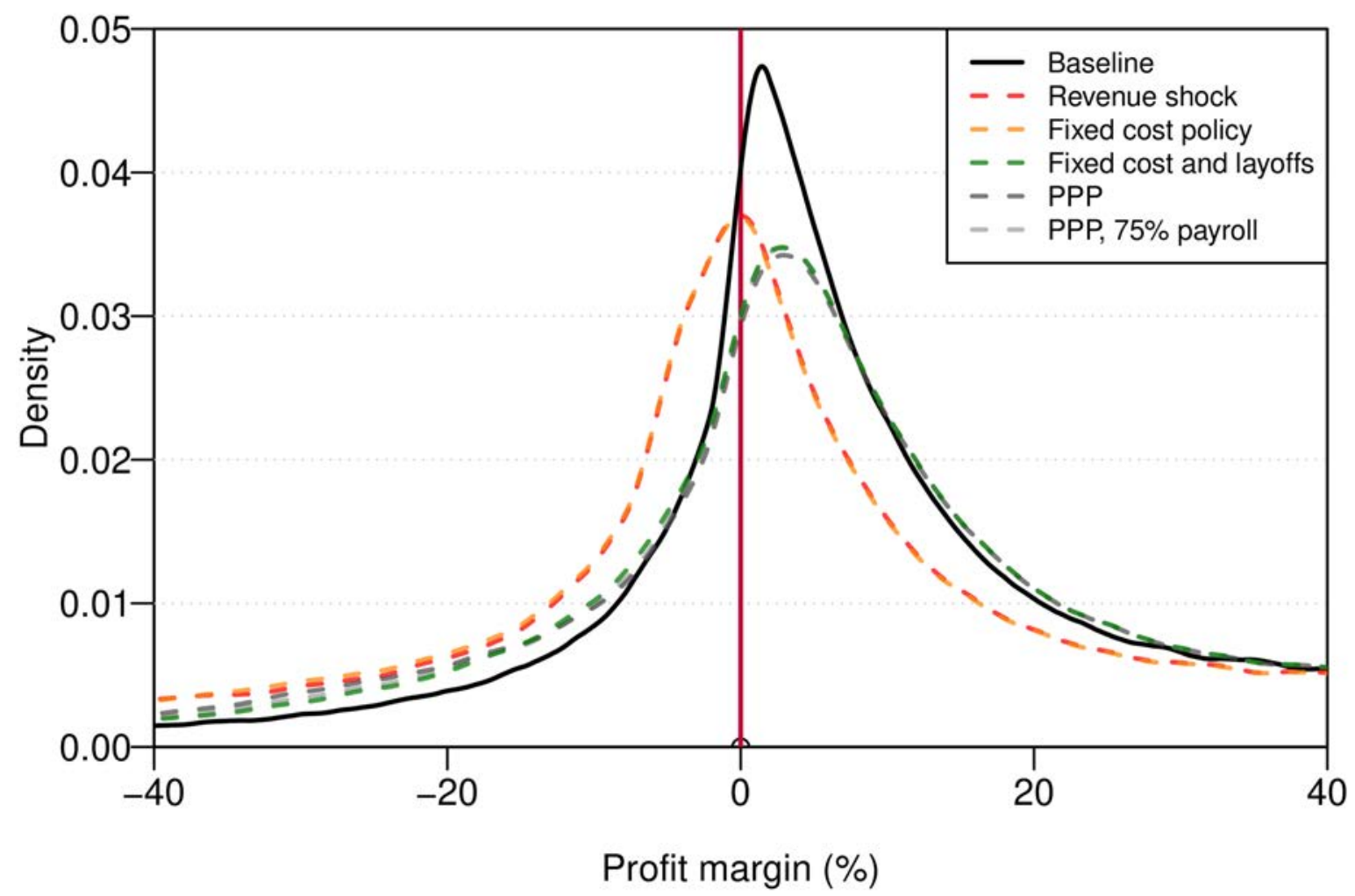

of $45 \%$, only about $33 \%$ of firms would continue having negative profits in the presence of strong government support (relative to the baseline of $28.8 \%$ ).

Interestingly, there is not a major quantitative difference in the impact of layoffs, PPP and PPP with a $25 \%$ payroll reduction. Layoffs perform slightly better than PPP and PPP with $25 \%$ payroll reduction performs slightly better than both of these. The main reason for these relatively small differences is that covering $41 \%$ of payroll (PPP) or saving on $66 \%$ of payroll (PPP with an additional $25 \%$ payroll reduction) should be contrasted with the alternative of laying off workers. The hardest hit firms, those that would be willing to lay off more than $66 \%$ of workers, will do so regardless under our assumptions. Firms that would want to layoff between $41 \%$ and $66 \%$ of workers will make different decisions under the two policies. Firms that would want to lay off fewer than $41 \%$ of workers are better off under PPP. Thus, PPP is a preferred option to layoffs for firms that are not the ones most suffering - it does provide an additional option and thus has to be beneficial, but its beneficial effect is not in the tail of the distribution. Finally, when compared to the Norwegian policy-based scenario, there is an additional option there of receiving compensation for fixed costs. Table 2 shows that this option happens to effectively offset the advantage of PPP unless we allow for 
Figure 7: The effect of the crisis on liquidity after 1 month

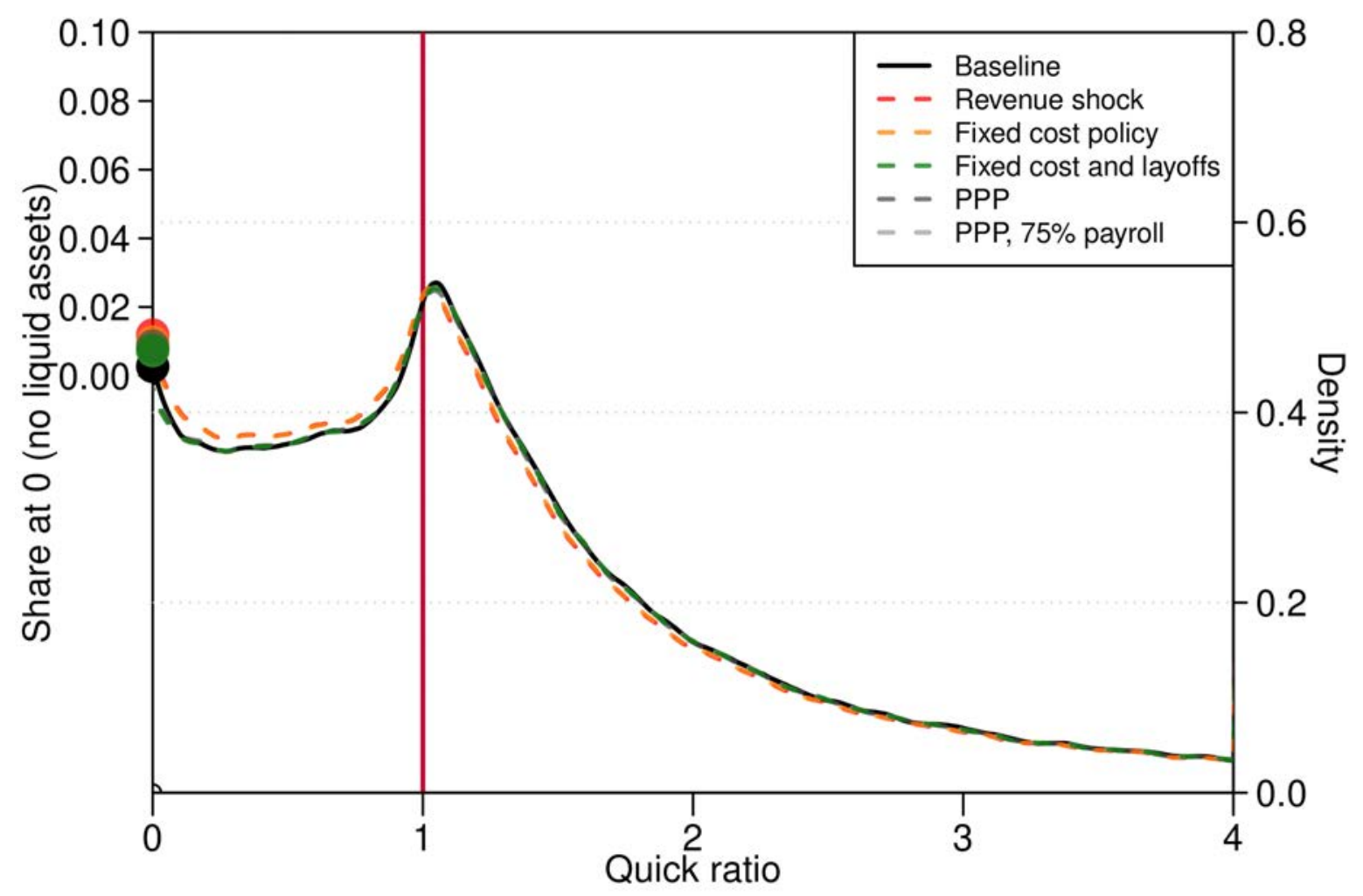

Notes: The figure shows the distribution of quick ratio after 1 month under the six scenarios described in text. We assume adjustment of liquid assets first so that a firm that runs out of them has the quick ratio of 0 . Thus, the distribution has a mass point at 0 . The right axis shows the pdf. The scale on the left axis shows the share of firms that would run out of liquid assets and have the quick ratio of 0 . The circles represent the mass point at 0 , the lines the pdf elsewhere. The left scale is adjusted so that the mass point under the baselines coincides with the corresponding continuous density as it approaches 0 .

an additional payroll reduction.

Protecting profits of firms is not the direct objective of these policy measures, but preserving jobs and preventing bankruptcies through reduscing firms' financial distress (in our context measured by illiquidity and insolvency) is. Figure 7 illustrates that a month-long shock deteriorates short-term liquidity position of firms, as measured by the "quick ratio" — the ratio of short-term current (liquid) assets minus inventories to current liabilities. We assume that this ratio adjusts by reducing current assets rather than additional borrowing. The shock shifts the distribution to the left and policies mitigate it. But, after just one month, this effect is mild. In particular, Table 2 shows that $1.2 \%$ of firms would run out of liquid assets (the quick ratio falling to zero).

However, as Figure 8 shows, these effects grow dramatically over time. In the case of a crisis that lasts 3 months, a nontrivial share of firms runs out of short-term liquid assets, 
Figure 8: The effect of the crisis on liquidity in response to a 3-month shock in revenue and policy

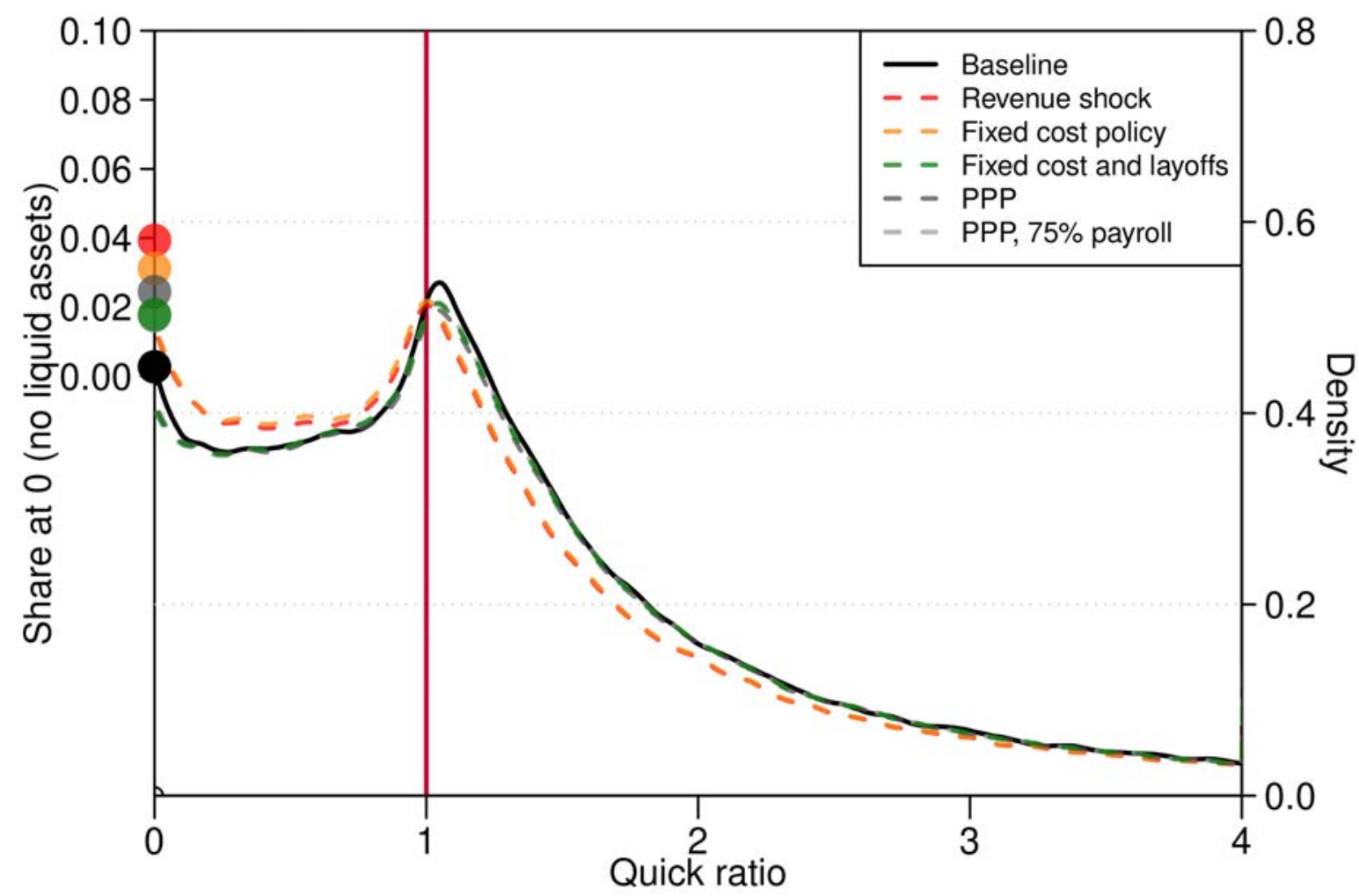

Notes: The figure shows the distribution of quick ratio after 1 month under the six scenarios described in text. We assume adjustment of liquid assets first so that a firm that runs out of them has the quick ratio of 0 . Thus, the distribution has a mass point at 0 . The right axis shows the pdf. The scale on the left axis shows the share of firms that would run out of liquid assets and have the quick ratio of 0 . The circles represent the mass point at 0 , the lines the pdf elsewhere. The left scale is adjusted so that the mass point under the baselines coincides with the corresponding continuous density as it approaches 0

so that our quick ratio measure is equal to zero, and has to rely on outside borrowing. Under unmitigated shock, $3.9 \%$ of firms would run out of liquid assets in order to cover their routine expenses. All policies mitigate it to some extent, with fixed cost compensation alone reducing it by $0.8 \mathrm{pp}$, layoffs adding another $1.3 \mathrm{pp}$ and the alternative US-based policies having a similar effect. After 6 months, as shown in Figure 9 all these effects grow $-8.1 \%$ of firms would run out of liquid assets, with the fully implemented Norwegian policy reducing it to $3.7 \%$, PPP with maintaining payroll to $5.1 \%$ and PPP with reduced payroll to $3.6 \%$.

Figure 10 shows the alternative measure of stress - the ratio of debt to assets - after a 3-month shock. We assume that firms will finance their shortfall by borrowing so that the debt ratio must increase. A debt ratio greater than one would indicate that the firm's debt exceeds assets and can be viewed as an indicator of insolvency risk, which in the end could lead to bankruptcy. As before, the shock has significant adverse consequences. The debt 
Figure 9: The effect of the crisis on liquidity in response to a 6-month shock in revenue and policy

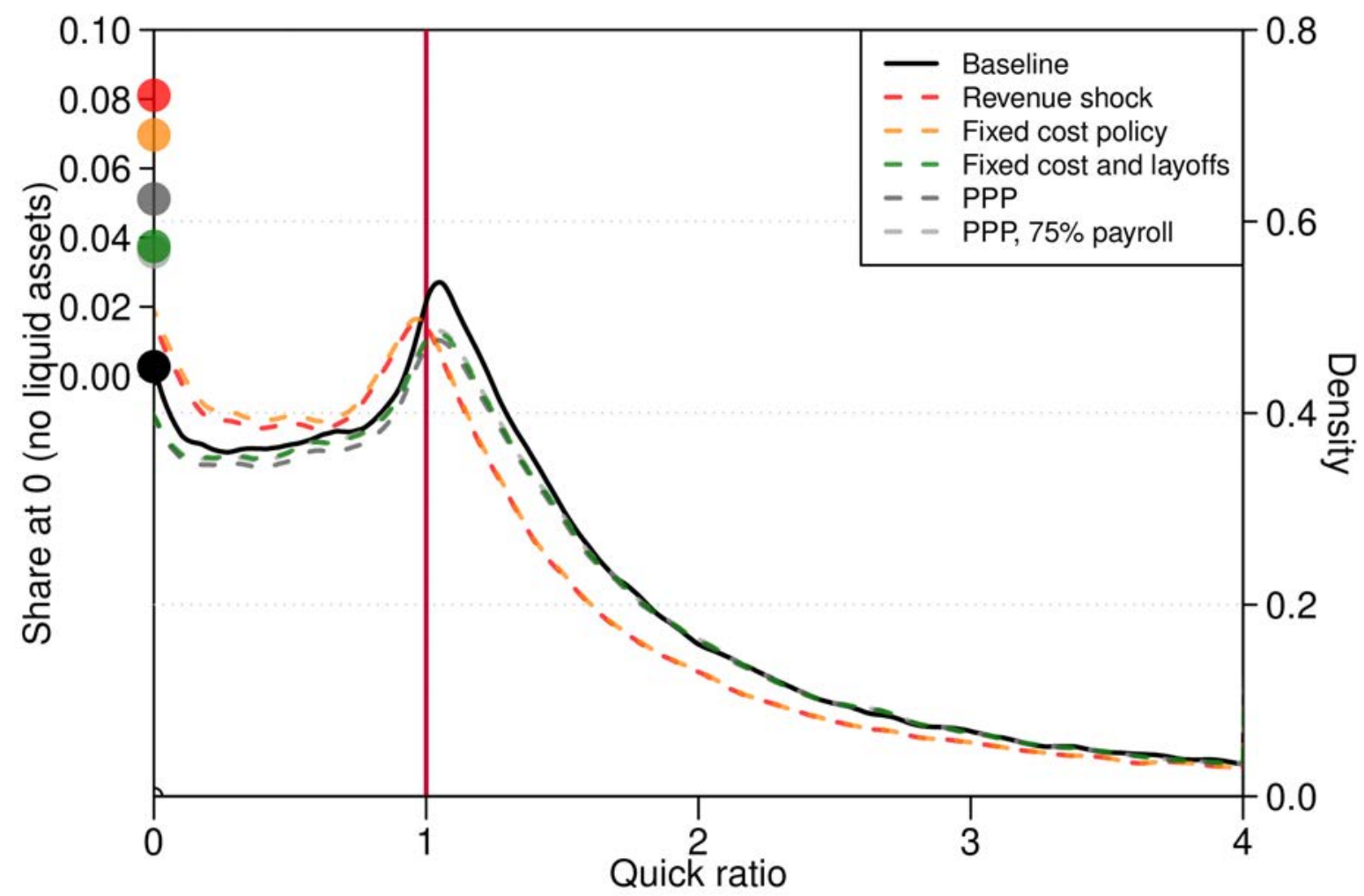

Notes: The figure shows the distribution of quick ratio after 6 months under the six scenarios described in text. We assume adjustment of liquid assets first so that a firm that runs out of them has the quick ratio of 0 . Thus, the distribution has a mass point at 0 . The right axis shows the pdf. The scale on the left axis shows the share of firms that would run out of liquid assets and have the quick ratio of 0 . The circles represent the mass point at 0 , the lines the pdf elsewhere. The left scale is adjusted so that the mass point under the baselines coincides with the corresponding continuous density as it approaches 0

ratio increases by 0.165 , so that the mean firm now has a debt ratio of 0.927 (Table 2) and the the share of firms with debt greater than assets increases from $15.1 \%$ to $21.3 \%$. The policy is effective in reducing the damage, with all interventions on the payroll side cutting the increase in debt ratio and in the number of firms with debt ratio over one by about a third.

\section{Conclusions}

We simulate the results of public policies in both Norway and the US on the common data set of the universe of active Norwegian corporations, which enables us to focus on the impact of policies rather than on the differences in the structure of the economies. The 
Figure 10: The effect of the crisis on debt ratio in response to a 3-month shock in revenue and policy

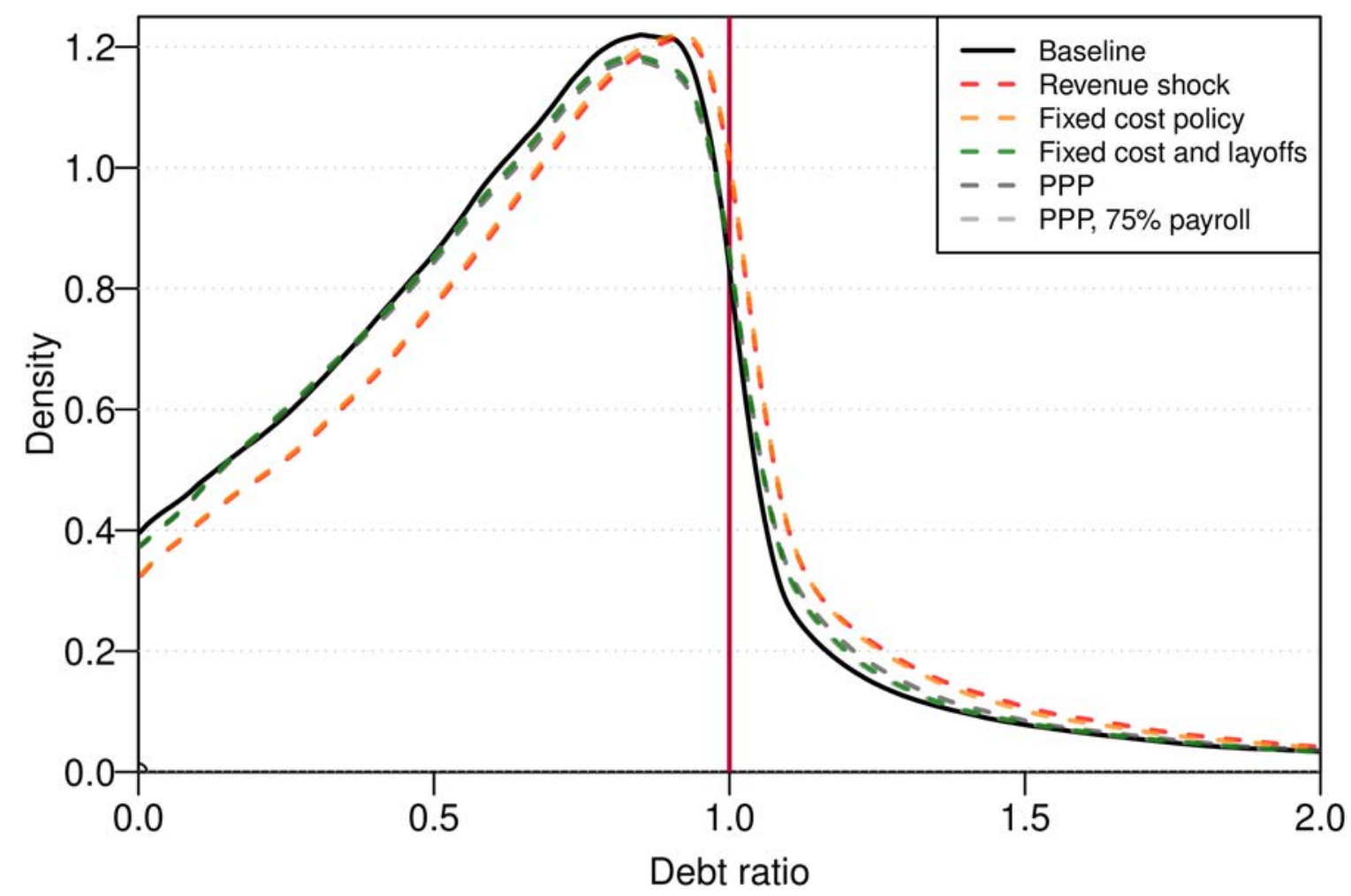

Norwegian economy is more export oriented and has a relatively larger industrial sector, though this is somewhat mitigated because we exclude the offshore oil industry from the sample. Correspondingly, Norwegian consumption relies more heavily on imports, accounting for a smaller share of domestic production. Another large difference between the countries is the size of the welfare state, the coverage of unemployment insurance and the structure of the labor market. This could mean that the longer-term effects of the various measures on labor market outcomes may be different in the two countries for reasons going beyond the different course of the crisis, but this relatively simple analysis framework cannot address such questions.

The Norwegian context allows for observing the magnitude of revenue shocks based on applications for assistance that firms filed early in the crisis. We consider scenarios that correspond to persistence of these shocks for up to 6 months. This is a somewhat stylized but, we believe, an interesting way to shed quantitative light on the potential impact of the crisis on the financial situation of firms. Norway is already significantly under way of reopening its economy as of July 2020, so that the assumption of 3-month persistence of the 
full shock is on the high side. In the case of the United States, the process of re-opening has also started, but the pandemic does not appear to be under control so that the 6 months assumption is more realistic and may still prove too optimistic. Of course, revenue losses in the following months do not need to be (and won't be) of the same magnitude and firms can adjust aspects of behavior that we do not model. Our work does not try to predict it, but instead attempts to illustrate the immediate liquidity, solvency and profitability implications of the crisis.

Our analysis focused on the ability of policies implemented in Norway and in the United States to mitigate the crisis. Somewhat surprisingly, we found that the full package of policies implemented in the two countries fares similarly well in terms of mitigating the damage to profits and, most importantly, liquidity and insolvency risk. The key aspect in both cases is support for payroll - either through a temporary unemployment scheme or through forgivable loans. In contrast, a fairly generous, at least on paper, Norwegian scheme that provides support for fixed costs turned out not to make an enormous quantitative difference, primarily because it did not turn out to be particularly well targeted to the more financially distressed firms. 
Table 2: Profits and liquidity under different scenarios

\begin{tabular}{|c|c|c|c|c|c|c|}
\hline & Baseline & $\begin{array}{l}\text { Revenue } \\
\text { shock }\end{array}$ & $\begin{array}{c}\text { Fixed cost } \\
\text { policy }\end{array}$ & $\begin{array}{l}\text { Fixed cost } \\
\text { and layoffs }\end{array}$ & PPP & $\begin{array}{c}\text { PPP, } 75 \% \\
\text { Payroll }\end{array}$ \\
\hline & \multicolumn{6}{|c|}{ After 1 month } \\
\hline Average profit rate & 0.099 & 0.090 & 0.091 & 0.097 & 0.096 & 0.097 \\
\hline Negative profits & 0.288 & 0.327 & 0.323 & 0.294 & 0.298 & 0.296 \\
\hline Average quick ratio & 2.813 & 2.783 & 2.789 & 2.843 & 2.837 & 2.843 \\
\hline Quick Ratio $<1$ & 0.389 & 0.413 & 0.411 & 0.394 & 0.396 & 0.393 \\
\hline Quick Ratio=0 & 0.003 & 0.012 & 0.010 & 0.007 & 0.009 & 0.007 \\
\hline Average debt ratio & 0.762 & 0.817 & 0.810 & 0.771 & 0.777 & 0.770 \\
\hline \multirow[t]{2}{*}{ Debt Ratio $>1$} & 0.151 & 0.172 & 0.170 & 0.156 & 0.158 & 0.156 \\
\hline & \multicolumn{6}{|c|}{ After 3 months } \\
\hline Average profit rate & 0.099 & 0.069 & 0.073 & 0.092 & 0.089 & 0.090 \\
\hline Negative profits & 0.288 & 0.385 & 0.380 & 0.309 & 0.316 & 0.311 \\
\hline Average quick ratio & 2.813 & 2.738 & 2.750 & 2.907 & 2.893 & 2.909 \\
\hline Quick Ratio <1 & 0.389 & 0.452 & 0.448 & 0.402 & 0.406 & 0.400 \\
\hline Quick Ratio $=0$ & 0.003 & 0.039 & 0.031 & 0.018 & 0.024 & 0.017 \\
\hline Average debt ratio & 0.762 & 0.927 & 0.906 & 0.789 & 0.808 & 0.787 \\
\hline \multirow[t]{2}{*}{ Debt Ratio $>1$} & 0.151 & 0.213 & 0.208 & 0.168 & 0.174 & 0.166 \\
\hline & \multicolumn{6}{|c|}{ After 6 months } \\
\hline Average profit rate & 0.099 & 0.031 & 0.040 & 0.081 & 0.073 & $\overline{0.077}$ \\
\hline Negative profits & 0.288 & 0.450 & 0.447 & 0.328 & 0.335 & 0.330 \\
\hline Average quick ratio & 2.813 & 2.699 & 2.713 & 3.013 & 2.995 & 3.017 \\
\hline Quick Ratio $<1$ & 0.389 & 0.497 & 0.494 & 0.412 & 0.418 & 0.411 \\
\hline Quick Ratio $=0$ & 0.003 & 0.081 & 0.070 & 0.037 & 0.051 & 0.036 \\
\hline Average debt ratio & 0.762 & 1.092 & 1.051 & 0.817 & 0.856 & 0.814 \\
\hline Debt Ratio $>1$ & 0.151 & 0.261 & 0.256 & 0.185 & 0.193 & 0.183 \\
\hline
\end{tabular}

Notes: The table presents six different scenarios as described in text: the baseline of no shock; the revenue shock with material cost adjustments only; the Norwegian policy covering share of fixed costs; fixed costs and layoffs; the US PPP scheme and the US PPP scheme with payroll of $75 \%$. Profit rate is annual, based on the crisis lasting for 1,3 , and 6 months respectively and the return to the baseline afterwards. 


\section{References}

Alstadsæter, Annette, Bernt Bratsberg, Gaute Eielsen, Wojciech Kopczuk, Simen Markussen, Oddbjorn Raaum, and Knut Røed, "The First Weeks of the Coronavirus Crisis: Who Got Hit, When and Why? Evidence from Norway," Working Paper 27131, National Bureau of Economic Research 2020.

Bachas, Pierre and Anne Brockmeyer, "Using administrative tax data to understand the implications of COVID-19 (coronavirus) for formal firms," Blog, The World Bank, Available at: https://blogs.worldbank.org/developmenttalk/ using-administrative-tax-data-understand-implications-covid-19-coronavirus-formal 2020.

Bennedsen, Morten, Birthe Larsen, Ian Schmutte, and Daniela Scur, "Preserving job matches during the COVID-19 pandemic: Firm-level evidence on the role of government aid," Covid Economics: Vetted and Real-Time Papers, 2020, 1 (27), 1-30.

Holden et. al., "Samfunns $\varnothing$ konomisk vurdering av smitteverntiltak - covid-19 Rapport fra ekspertgruppe på oppdrag for Helsedirektoratet 7. April 2020," report, Norwegian Directorate of Health 2020.

Markussen, Simen, Gisle Natvik, and Fredrik Wulfsberg, "Alternative kompensasjonsordninger for næringslivet med vekt på lønnsutgifter - anslagsvise beregninger av fordelings- og insentiveffekter," Report, The Frisch Centre, Available at: https://fagarkivet-hioa.archive.knowledgearc.net/bitstream/handle/20. 500.12199/3124/Kompordning_data_rev_RF.pdf?sequence=1\&isAllowed=y 2020. 


\section{A Detailed description of the Norwegian Covid-19 economic crisis measures}

Following the lockdown, the Norwegian government introduced a range of economic measures to counter the economic shock 12 This section presents some of the most important measures, focusing on the enhanced temporary layoff scheme and the new compensation scheme for businesses, which are also central to the analysis.

Enhanced temporary layoff scheme. One of the first responses to the lockdown was an enhancement of the rules regarding temporary layoffs and unemployment insurance. Workers may be laid off temporarily or permanently. Both options qualify for unemployment insurance.

On March 16, the Norwegian parliament agreed to change the rules for layoffs with immediate effect.

- First 20 days: $100 \%$ compensation up to an annual income limit of approximately NOK 600,000 — about USD 56,000.

- After 21 days: $100 \%$ of annual income under NOK 300,000 and $62.4 \%$ for annual income between NOK 300,000 and 600,000.

- No compensation for lost income above NOK 600,000 (annually).

Prior to the rule change, unemployed were compensated with $62.4 \%$ for annual income up to 600,000 NOK. Employers' responsibility to pay laid off in full was also reduced from 15 to 2 days. The payment was set to be made as soon as the technical solutions were in place.

The new compensation scheme for businesses. On March 27 the government announced a compensation scheme for fixed, unavoidable costs for businesses that experienced a substantial revenue loss as a result of the virus outbreak. The specific rules were announced on April 2. Legislation passed parliament on April 713 The minimum revenue loss was set to $20 \%$ in March and $30 \%$ in April and May.

For businesses that were closed down by the state, the compensation for a given month is calculated as

- Compensation $=$ Revenue loss $\times$ Fixed, unavoidable costs $\times 90 \%$

For businesses that were not closed down by the state, the compensation for a given month is calculated as

\footnotetext{
${ }^{12}$ For detailed information, see https://www.regjeringen.no/no/aktuelt/economic-measures-in-norway-inresponse-to-covid- 19/id2696858.

${ }^{13}$ Rules adjusted somewhat May 15, for more information see: https://www.regjeringen.no/id2702881/
} 
- Compensation $=$ Revenue loss $\times($ Fixed, unavoidable costs - Deduction $) \times 80 \%$

This deduction was NOK 10,000 for March and NOK 5,000 for April.

The fixed, unavoidable costs that are eligible for compensation include rent costs, electricity costs, insurance costs, interest income less interest payments.

If the business was established in March 2019 or earlier, the revenue loss is calculated as

- Revenue loss $=\frac{\text { Rev. in month in } 2019 \times \frac{\text { Rev. Jan-Feb } 2020}{\text { Rev. Jan-Feb 2019 }- \text { Rev. in month in } 2020}}{\text { Rev. in month in } 2019 \times \frac{\text { Rev. Jan-Feb 2020 }}{\text { Rev. Jan-Feb } 2019}}$

For businesses that were established in April 2019, it becomes

- Revenue loss $=\frac{\text { Revenue Jan-Feb } 2020-\text { Revenue in month in } 2020}{\text { Revenue Jan-Feb } 2020}$

If the calculated subsidy is less than NOK 5,000, the subsidy will not be paid. If the calculated subsidy is more than NOK 30 million, the amount above NOK 30 million will be halved when the subsidy is paid out. The subsidy amount may not exceed NOK 80 million.

Other criteria that must be met for a firm to qualify for the scheme are:

- It is liable to pay tax to Norway.

- It was registered before March 12020.

- It has employees.

- It has fulfilled its reporting obligation.

- It has not entered bankruptcy proceedings, nor has a bankruptcy petition been submitted.

- It has unavoidable fixed costs.

- It must not operate within industries that are excluded from the scheme, mainly because these are covered by other crisis measures: finance industry, oil and gas production companies that fall under the oil taxation regime, companies that produce, transfer or distribute electricity, airlines with a Norwegian operating license, private daycare centers.

\section{Other fiscal measures.}

Other measures included extra spending on health care and relaxation of tax and pension rules to attract students and retirees with medical training into the labor force.

Self-employed and freelancers were given sick-leave benefits from day four and temporary income protection equivalent to $80 \%$ of the average of the last three years of income up to 600,000 . This compensation applied from day 17 after the loss of income. 
A guarantee scheme was also announced to ensure liquidity for businesses, and the Government Bond Fund was restored. The scheme was specifically aimed at new bank loans to small and medium-sized businesses that suffered operating losses due to the extraordinary situation related to the outbreak of Covid-19.

The payroll tax was cut, and the VAT payments deferred. Companies with deficits in 2020 were able to carry back losses. Owners of companies that report deficits in 2020 can defer payments of wealth tax. The remittance of the payroll tax was also deferred to help liquidity. For airlines, there was a temporary cancellation of the air passenger tax for flights taking place between 1 January and 31 October 2020, and all airport fees were canceled up to and including 30 June 2020.

Bankruptcy law. In Norway, a creditor must petition the court for a bankruptcy proceeding, which entails a cost, before bankruptcy can be opened. If the court finds that the firm is insolvent, a bankruptcy proceeding is formally opened and the control over firm's assets is transferred to a trustee, who oversees assets and claims and attempts to settle debts to creditors. There is bankruptcy protection during restructuring as in the US Chapter 11 proceedings, that are intended to secure future operation of firms with liquidity problems. Norwegian bankruptcy proceedings usually result in liquidation of the firm. As a temporary Covid-19 measure, the government has expanded existing debt negotiation procedures (which seldom are used), to enable firms to attempt solving their debt problems without going bankrupt 14

\footnotetext{
${ }^{14}$ Read more at https://www.regjeringen.no/id2697585/.
} 